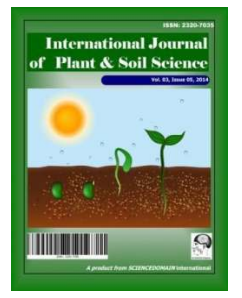

\title{
Effects of Watering Regime and Rhizobium Inoculation on the Growth, Functional and Yield Traits of Four Legume Species
}

\author{
S. O. Agele ${ }^{1^{*}}$, A. J. Ajayi ${ }^{2}$ and F. M. Olawanle ${ }^{1}$ \\ ${ }^{1}$ Department of Crop, Soil and Pest Management, Federal University of Technology, Akure, Nigeria. \\ ${ }^{2}$ Department of Horticulture, Federal College of Agriculture, Akure, Nigeria. \\ Authors' contributions \\ This work was carried out in collaboration between all authors. Authors SOA and AJA designed the \\ study. Authors AJA and FMO performed the statistical analysis. Authors SOA and AJA wrote the \\ protocol, authors SOA and FMO wrote the first draft of the manuscript. Authors SOA and AJA \\ managed the statistical analyses of the study. Author FMO managed the literature searches. All \\ authors read and approved the final manuscript.
}

Article Information

DOI: $10.9734 /$ IJPSS/2017/32891

Editor(s):

(1) Yong In Kuk, Department of Development in Oriental Medicine Resources, Sunchon National University, South Korea.

(2) Surendra Singh Bargali, Department of Botany, DSB Campus, Kumaun University, Nainital, Uttarakhand, India.

Reviewers:

(1) Juan Sanjuan, Estacion Experimental del Zaidin, Spain.

(2) Ilkay Yavas, Adnan Menderes University, Turkey.

(3) Hamza Abdulmajeed, University of Ibadan, Nigeria.

Complete Peer review History: http://www.sciencedomain.org/review-history/20078

Original Research Article

Received 21 ${ }^{\text {st }}$ March 2017

Accepted $19^{\text {th }}$ May 2017

Published $17^{\text {th }}$ July 2017

\begin{abstract}
The effects of watering regime and rhizobial inoculation on the growth, nodulation and seed yields of some legume species was evaluated in the screenhouse of the Department of Crop, Soil \& Pest Management, Federal University of Technology, Akure, Nigeria. The experimental layout was $5 \times 3$ x 2 factorial with 3 replications given a total of 90 treatments. Seeds of five staple and forage legume species: Pakala (Phaseolus lunatus), Soy bean (TGX 199057f' and TGX198057), Stylozanthes (Stylozanthes macrocephala) and the Greenleaf Desmodium (Desmodium intortum (Mill.) Urb.) were sown into plastic pots which were watered at 4-, 8- and 12- days intervals, with or without rhizobium inoculation using a rhizobium strain, Rhizobium phaseoli. The plastic pots (5 litre capacity were perforated at bottom to allow for drainage and were filled with pure river sand. The effect of watering regimes on legume species was significant on leaf development, soybean
\end{abstract}


variety, TGX199057f had the highest number of leaves while Desmodium had the least number of leaves. Seedlings that were watered at 4- and 8-days interval had better vigour of growth compared to 12- days watering interval. Compared with 12-days watering interval, both inoculated and non-inoculated seedlings subjected to 4- and 8-days watering intervals had higher root and shoot biomass. TGX $199057 \mathrm{f}$ non- inoculated at 8-days watering intervals had the highest value for number of pods and TGX198057 watered at 12- day intervals had higher pod weight. Rhizobium inoculated legumes produced more vigorous plants in addition to higher root nodules, plant height and number of leaves compared with the non-inoculated species. The highest number of leaves and nodules were produced by Phaseolus lunatus when inoculated with the rhizobium strain. However, the highest number of pods was obtained for inoculated soybean (TGX 199057f) compared with the non-inoculated plants. The highest seed yield was obtained from rhizobium inoculated soybean (TGX 198057). Desmodium produced few seeds compared to Phaseolus lunatus and Styolzanthes. The effects of watering regimes and rhizobium inoculation varied on leaf proximate and chemical composition of legume species. The nitrogen, crude protein, ash, chlorophyll, soluble carbohydrates content in leaf differed among the legume species. The legume species inoculated and grown at 4- days watering intervals had the highest contents of moisture, nitrogen, chlorophyll, soluble carbohydrates and ash compared to non-inoculated legume species. Application of rhizobium strain significantly increased seed yield in soybean and Desmodium and caused substantial increase in nodulation. The study has shown that to increase legume productivity under soil moisture deficit stress of marginal/degraded soil, application of rhizobium inoculant is recommended.

Keywords: Soil moisture; stress; root nodule; legumes; growth; seed; chemical; proximate.

\section{INTRODUCTION}

Legumes belong to the family Fabaceae (formerly Leguminosae). Legumes are grown primarily for their seed, for livestock forage and silage and as soil enhancing green manure. Legumes are notable in that most of them have symbiotic nitrogen fixation -fixing bacteria in structure called root nodules [1]. Legumes are plants with seed pods that split into two halves. Edible seeds from plants in the legume family include beans, pea, lentils, soy bean and peanuts. Although legumes are an important part of traditional diets around the world, they are often neglected in typical western diet [2]. Legumes are important sources of animal protein are often rich in saturated fats, the small quantities of fats in legumes are mostly unsaturated. Legumes are among the best protein sources in the plant kingdom. Since legumes are relatively cheap compared to meat, eating more legumes may be an alternative to meat [2]. Legumes differ from grasses and cereals and other non- legume crops because much of the nitrogen they require is produced through fixation of atmospheric nitrogen by bacteria in nodules on their roots [3,4]. Legumes are economically important in addition to its use in many cropping systems because of their ability to assimilate atmospheric nitrogen by root nodules bacteria [5]. Forage legumes are adapted to acid and low fertility soils, even though they show high responses to fertilizers. Stylozanthes and Desmodium spp. are perennial tropical forage legumes. Leguminous forage plants, characterized by their capacity to biologically fix atmospheric nitrogen in the soil, their introduction into pasture or rangelands will improve livestock diet and reducing nitrogen fertilizers, provide feed resource relevant to attain increases in animal production [4].

Legumes have the ability to form a mutually beneficial (symbiotic) relationship with certain soil bacteria of their type [5]. These bacteria can fix nitrogen from the air and make it available to the plant via symbiotic nitrogen fixation [6]. The amount of nitrogen fixed can meet the needs of the plant and leave nitrogen in the soil for the following crop. Many legumes contain symbiotic bacteria called rhizobia within root nodules of their root systems. These bacteria have their special ability of fixing nitrogen from atmospheric molecular nitrogen $\left(\mathrm{N}_{2}\right)$ into ammonia $\left(\mathrm{NH}_{3}\right)$ [7]. Under nitrogen limiting conditions, the leguminous plant will form root nodules where the bacteria are hosted and will find the proper conditions to reduce atmospheric nitrogen into ammonia $[7,8]$. Symbiotic nitrogen fixation largely contributes to the nitrogen nutrition of the host plant suppressing the needs for nitrogen fertilizers. Incorporating legume crops into cropping system will improve nitrogen and carbon sources to the soil for subsequent crops 
[8]. Rhizobium is a common soil bacterium, not toxic to humans, plants or animals. It is one of the most beneficial bacteria to agriculture $[8,9]$. Rhizobia are very minor components of the soil micro flora and reach their maximum numbers in association with plant roots $[6,10]$. They are stimulated by carbon compounds in plant roots and are controlled by microbial competition. Their ability to infect legume roots and multiply within the resulting root nodules protected from the soil environments provides a special advantage over their competitors [11,12].

Drought considerably reduces legumes species productivity, especially in areas where agricultural system is dependent on rainfall. Drought is among the most difficult challenges faced by resource poor farmers [4]. Water stress and excess water can have adverse effects on nodulation and nitrogen fixation [13,14]. Water stress is one of the major causes of reduced growth, development and yield in leguminous plants and also reduces nitrogen fixation and its related traits [14]. Legumes are very sensitive to drought which leads to reduced yield and seed quality. Water stress is a major factor affecting symbiosis and leads to decreased nodule formulation, reduced nodule size and $\mathrm{N}_{2}$ fixation $[15,16]$. Leguminous plants in association with rhizobium species have the potential to fix large amount of atmospheric nitrogen which contributes to the soil nitrogen pool provided that the nitrogen fixation is not restricted by other environmental or microbial factors [17]. Nitrogen fixation is the process whereby legume crop and specific rhizobium bacteria work together to make nitrogen from the soil air surrounding the roots available for use by the plant [14]. The $\mathrm{N}$ fixation process requires a considerable amount of energy which is provided by the plant. The plant provides nutrients and water to the rhizobia in the nodules and in return, the rhizobia provided fixed nitrogen to the plant. The amount of $\mathrm{N}$ fixed varies with the type of crop, crop health, the supply of nitrogen already available in the soil and other environmental conditions [2 ,18]. Rhizobium inocula are living culture of bacteria but are mostly sensitive to heat desiccation and light [19-21]. Nitrogen fixation in legumes depends on the formulation of nodules by rhizobium. Rhizobium is a common soil bacterium and among rhizobium strains commonly used as inoculants for introduction to soils are Rhizobium phaseoli, R. leguminosarum bv trifolii and $R$ japonicum. Some rhizobium are specific and nodulated several legumes [22]. Inoculation is the process of introducing the appropriate rhizobium bacteria to the soil in numbers sufficient to ensure successful nodulation [23].

Global legume production increased from 150 million tons in the 1980's to 300 million tons in the 2000's. Legume production is dominated by soybean while pulses accounted for approximately $20 \%$ of total production during the same period [24]. This challenge is further compounded by the severe competition for land and water from industry and urban development. Such competition pushes agriculture to marginal areas, where water-limiting conditions often constrain crop productivity. Besides the persistent water limitation and year to year fluctuations of meteorological conditions in these marginal areas (e.g., semi-arid environments) tend to be large, and these variations significantly affect food security in these rain-fed systems. Drought can have negatively impact on the yield of most cultivated crops, from monocotyledons $\mathrm{C}_{4}$ (e.g., maize) to di-cotyledons $\mathrm{C}_{3}$ cereals (e.g., wheat) and legumes [4,14]. The yield of food legumes are usually variable or low due to terminal drought that characterize these areas [25]. Even in non-dry land where precipitation is generally sufficient for legume (i.e., soybean) cultivation, water deficiency may still occur over a period of a few weeks, causing significant yield loss [26].

A more effective and cheaper way of raising the $\mathrm{N}$ status of the soil is to exploit the ability of legumes to fix appreciable quantities of atmospheric nitrogen. Therefore, the specific objectives of the study are to examine the effects of the effect of watering regime and rhizobia inoculation on the growth, seed yield and yield components of some legumes species, nodulation and nitrogen fixation capacities of some legumes species and the leaf chlorophyll and soluble carbohydrate concentration as drought tolerance traits in legumes species.

\section{MATERIALS AND METHODS}

The experiment was conducted in the screen house of the Department of Crop, Soil and Pest Management, Federal University of Technology Akure, located in the rain forest area of south western Nigeria from January - August 2015. In the screen house, temperature and relative humidity fluctuated between $25-31{ }^{\circ} \mathrm{C}$ and 58 $85^{\circ} \mathrm{C}$ respectively, during the period of the experiment. 


\subsection{Planting Materials}

Seeds of five staple and forage legume species were obtain from the International Institute of Tropical Agriculture (IITA), Ibadan, Nigeria The species are: Pakala (Phaseolus lunatus), Soy bean (TGX 199057f)' and TGX198057, Stylo (Stylozanthes macrocephala) and the Greenleaf Desmodium (Desmodium intortum (Mill.) Urb.). The seeds were planted into 5 liter buckets perforated at bottom to allow for drainage. The pots were filled with pure river sand obtained from a flowing river in Akure. A rhizobium strain, Rhizobium phaseoli, was obtained from the International Institute of Tropical Agriculture, Ibadan.

\subsection{Treatments and Experimental Design}

The experimental layout was $5 \times 3 \times 2$ factorial arranged in a Completely Randomized Designed (CRD) with 3 replications (total of 90 treatments). Treatments consisted of 5 staple and forage species, 4,8 and 12 days watering intervals and with or without rhizobium inoculation. At each watering interval, $900 \mathrm{ml}$ of water was applied throughout the experiment.

\subsection{Data Collection}

Measurement of agronomic variables commenced 3 weeks after planting and lasted for a period of 8 months. The variables include number of leaves, plant height, number of branches, number of nodules, nodules weight, nodules diameter, number of pods, pod weight ,number of seeds ,seeds weight, days to $50 \%$ flowering, soil chemical properties, Leaf samples were collected and analyzed for soluble carbohydrate, chlorophyll, ash, nitrogen, crude protein ,moisture content and crude fibre. These parameters were determined in the following ways: The number of leaves per plant: This was estimated by counting. The plant height: This was measured using measuring tape. The measurement was taken from the base to the apical shoot. The number of branches per plant: This was estimated by counting. Number of nodules: This was done by visual counting of nodules borne on root after terminating the experiment. Nodule weight: The nodules of each plant were removed and weighed using a weighing balance. Nodule diameter: This was measured with the use of Vernier calliper. Number of pods: This was done by visual counting of pods borne on each plant at harvest. Number of seeds: This was done by visual counting of seeds after removal from pod. Seed weight: This was done by weighing the seeds on weighing balance. The date to $50 \%$ flowering: This was determined when the plants produces maximum flowers during the growth stage.

\subsection{Determination of Selected Soil Physical and Chemical Properties}

The soil texture was determined using part of the soil samples collected for the experiment; this was set aside before the contamination of the remaining part. The soil was air-dried to reduce the moisture content after which it was taken to the laboratory where the soil texture class was determined as sandy-loam as defined according to $\mathrm{FAO/USDA}$ soil classification system. Soil $\mathrm{pH}$ was determined by using 1:1 water suspension by adding $10 \mathrm{ml}$ distilled water to $10 \mathrm{~g}$ of soil. The suspension was stirred continuously for 30 minutes allowed to stand for 20 minutes. After calibrating the $\mathrm{pH}$ meter with buffer solutions of $\mathrm{pH} 4.0$ and 7.0 , the $\mathrm{pH}$ was read by immersing the electrode into the upper part of the suspension. Organic carbon was determined by a modified Walkley-Black wet oxidation method. Soil organic matter of the soil sample was calculated by multiplying the per cent organic carbon by a Van Bemmelen factor of 1.724.Potassium and sodium in the soil extract were determined by flame photometry. Standard solutions of $0,2,4,6,8$ and $10 \mathrm{ppm} \mathrm{K}$ and $\mathrm{Na}$ were prepared by diluting appropriate volumes of $100 \mathrm{ppm} \mathrm{K}$ and $\mathrm{Na}$ solution to $100 \mathrm{ml}$ in volumetric flask using distilled water. Flame photometer readings for the standard solutions were determined and a standard curve constructed. Potassium and sodium concentrations in the soil extract were read from the standard curve. Available $P$ was determined using the Bray P1 method. The method is based on the production of a blue complex of molybdate and orthophosphate in an acid solution. A standard curve was constructed using the readings. The concentration of $P$ in the extract was obtained by comparison of the results with a standard curve. For the determination of calcium, a $10 \mathrm{ml}$ portion of the extract was transferred into an Erlenmeyer flask. To this, $10 \mathrm{ml}$ of potassium hydroxide solution was added followed by $1 \mathrm{ml}$ of triethanolamine. Few drops of potassium cyanide solution and few crystals of cal-red indicator were then added. The mixture was titrated with $0.01 \mathrm{M}$ EDTA (ethylene diaminetetra acetic acid) solution from a red to a blue end point. The exchangeable magnesium alone was calculated 
by subtracting the value obtained from calcium alone from the calcium + magnesium value.

\subsection{Extraction and Determination of Leaf Chlorophyll}

Chlorophyll extraction and its determination were done at the laboratory of the Department of Crop, Soil and Pest Management, Federal University of Technology, Akure. The 2 uppermost leaves of legumes species from each treatment were harvested. One gram of the fresh plant samples were cut into pieces and smashed in a mortar. The samples were put in a test tube and its chlorophyll content was repeatedly extracted with successive volume of $100 \mathrm{ml}$ acetone/water $(80: 20 \mathrm{v} / \mathrm{v})$ until no traces of green colour were noticed(residue became white).While adding the solvent (acetone),the test tubes containing the samples were kept boiling in hot water bath. The total volume of the extract was also recorded at end of the extraction. Three millimeter $(3 \mathrm{ml})$ of the extract was taken and the absorbance was determined with a spectrophotometer (Spectronic 20) at two wave length of 663 and $645 \mathrm{~nm}$ that corresponds to maximum absorption of chlorophyll "a" and "b" respectively. The total chlorophyll content was calculated as follows:

Total chlorophyll content $(\mathrm{mg} / 100 \mathrm{~g}$ tissue $)=$ $(20.2 \mathrm{~A} 645+8.02 \mathrm{~A} 663)(\mathrm{V} / 10 \mathrm{w})$

Where, $\mathrm{A} 645=$ absorbance at $645 \mathrm{~nm}$ wavelength; $663=$ absorbance at $663 \mathrm{~nm}$ wavelength,

$V=$ final volume $\left(\mathrm{cm}^{3}\right)$ of chlorophyll extract in $80 \%$ acetone and $\mathrm{W}=$ fresh weight $(\mathrm{g})$ of tissue extracted

\subsection{Determination of Leaf Water Soluble Carbohydrate}

About $2 \mathrm{ml}$ of extracts were pipetted into a test tube. $10 \mathrm{ml}$ of anthrone reagent was rapidly added and mixed by shaking and placed in a boiling water bath. The absorbance of the extract was determined on a spectrophotometer device (using a $10 \mathrm{~mm}$ diameter cuvette). About $0.5 \mathrm{~g}$ of plant samples were ground and transferred into $250 \mathrm{ml}$ test tube and $220 \mathrm{ml}$ of water was added. The bottles was capped and shaken on a shaker for about an hour and filtered. The first few $\mathrm{ml}$ was ejected and the filtrate was retained for the determination of soluble carbohydrate using Antrone reagents. $770 \mathrm{ml}$ of concentrated $\mathrm{H}_{2} \mathrm{SO}_{4}$ was added to $330 \mathrm{ml}$ of distilled water, in addition to $1 \mathrm{~g}$ of thiourea, $1 \mathrm{~g}$ of antrone, stired until dissolved and was stored in a refrigerator. Glucose stock solution, $1 \mathrm{~g}$ of anhydrous D (+) glucose in water and diluted to one litre prepared immediately before use. From the glucose working standard solutions, $10 \mathrm{ml}$ of stock to 100 $\mathrm{ml}$ was diluted to produce $100 \mathrm{ppm}$. From these, $0,5,10,20,40,80 \mathrm{ml}$ was pipetted and made up to $100 \mathrm{ml}$ and these produced $0,5,10,20,40,80$ $\mathrm{ppm}$. Samples of $2 \mathrm{ml}$ of each glucose working standard solutions were pipetted into the glass test tube and rapidly, $10 \mathrm{ml}$ of anthrone reagent was added and mixed by shaking. The test tube was loosely covered with a glass bulb stopper and placed immediately in boiling water for 20 minutes. The absorbance was measured using spectrophotometer device in a $10 \mathrm{~mm}$ optical cell at $620 \mathrm{~mm}$. The graph of absorbance was plotted against glucose concentration in $\mathrm{ppm}$ and prepare standard graph with each batch of extracts examined. The glucose standard becomes $0, \quad 0.8,1.7,3.3,6.7,13.3$ ppm respectively.

Data collected on plant and soil parameters were subjected to analysis of variance (ANOVA) and treatment means were separated using Least Significant Difference (LSD) at $5 \%$ level of probability and Duncan Multiple Range Test (DMRT).

\section{RESULTS}

\subsection{Pre-experiment Soil Chemical Properties}

Table 1 shows the result of soil chemical properties before the experiment. The $\mathrm{pH}$ of the soil was 5.11 . Organic matter contents analysed was $1.11 \%$ Nitrogen content was $0.07 \mathrm{~g} / \mathrm{kg}$. The available $P$ content in the soil was $0.73 \mathrm{mg} / \mathrm{kg}, \mathrm{K}$ $(0.14 \mathrm{cmol} / \mathrm{kg}), \quad \mathrm{Na}(0.24 \mathrm{cmol} / \mathrm{kg}), \mathrm{Ca}(1.89$ $\mathrm{cmol} / \mathrm{kg}), \mathrm{Mg}(1.29 \mathrm{cmol} / \mathrm{kg})$.

Table 1. Pre-experiment soil chemical properties

\begin{tabular}{ll}
\hline Chemical properties & Values \\
\hline $\mathrm{pH}\left(\mathrm{H}_{2} \mathrm{O}\right)$ & 5.11 \\
$\mathrm{SOM}(\%)$ & 1.11 \\
Total $\mathrm{N}(\%)$ & 0.05 \\
Available $\mathrm{P}(\mathrm{Bray}-1)(\mathrm{mg} / \mathrm{kg})$ & 0.73 \\
Exch. $\mathrm{K}(\mathrm{cmol} / \mathrm{kg})$ & 0.14 \\
Exch. $\mathrm{Na}(\mathrm{cmol} / \mathrm{kg})$ & 0.24 \\
Exch. $\mathrm{Ca}(\mathrm{cmol} / \mathrm{kg})$ & 1.89 \\
Exch. $\mathrm{Mg}(\mathrm{cmol} / \mathrm{kg})$ & 1.29 \\
\hline
\end{tabular}




\subsection{Effects of Rhizobium Inoculationon Soil Chemical Properties}

Table 2 showed the result of soil chemical properties at the end of the experiment. The inoculated legume species had higher $\mathrm{pH}$. Desmodium and TGX 198057 had higher chemical properties than other legume species. There was no significant difference $(P<0.05)$ for Nitrogen. The same trend was observed for $\mathrm{Na}$, $\mathrm{Ca}$ and available $\mathrm{P}$. The increase in the nutrients content was significantly higher than pre experiment status $(P>0.05)$.

\subsection{Effects Watering Regimes on Growth of Legume Seedlings}

There were significant differences $(p<0.05)$ in the responses of legume seedlings on the measured growth parameters. The time course of the effects of species on plant height is presented in Table 3. Phaseolus lunatus watered 4-days was the tallest while TGX $199057 f$ had the lowest height at 12 days watering interval compared with Stylozanthes and Desmodium which had the highest plant height at 8 days watering interval. Significant differences occurred between species for number of branches. legume seedlings watered at 4- days interval had the highest number of branches compared with 8 and 12 days watering interval. Similarly, the effect of watering regimes on legume species was significant on number of leaves except at 3 weeks after planting (Table 3) there seems to be no consistent trend in leaf production in Phaseolus lunatus at 4 days watering interval. Significantly TGX199057f had the highest number of leaves across the period of measurement while Desmodium had the least number of leaves.

\subsection{Effects of Watering Regimes on Growth and Yield Parameters of Legume Species}

Table 4 shows the effects of watering regime on growth character of legume seedlings. Seedlings that were watered at 4 and 8 days interval enhanced high growth character compared to 12 days watering intervals across the different periods of observation. Table 6 shows the effects of watering regimes on growth and yield parameters of legumes seedlings. The seedlings that were watered at 4 and 12 days interval had higher number of nodules, pods, seed weight, flowers and longer root compared to 12 days watering interval.

\subsection{Effects of Rhizobium Inoculation on Growth Parameters of Legume Seedlings}

Rhizobium inoculated legume seedlings produced significantly higher growth characters especially the plant height, number of leaves compared with the non-inoculated species. (Table 5). Plant height was significantly affected by treatments (Table 5). Highest plant height was observed in inoculated Phaseolus compared with the non- inoculated. The mean values for legumes species also show significant difference in plant height. Rhizobium inoculation treatments also gave superior results compared with the non-inoculated. Rhizobium inoculation enhanced number of leaves (Table 5). More leaves were found in inoculated plant compared with noninoculated. Among the legume species differences in values indicates that the five legume species behaved differently, however highest number of leaves were produced by inoculated Phaseolus.

\subsection{Effects of Rhizobium Inoculation on Growth and Yield Parameters of Legume Species}

Table 6 shows the effects of rhizobium inoculation on number of roots per plant, number of nodules per plant, number of pods and seed yield per plant. The number of roots per plant was significantly affected by various treatments. Higher number of roots was produced by Phaseolus lunatus inoculated with rhizobia.

Table 2. Soil chemical properties taken from the legume species at termination of experiment

\begin{tabular}{|c|c|c|c|c|c|c|c|c|}
\hline & $\mathrm{pH}$ & Om & $\mathbf{N}$ & $\mathbf{P}$ & $\mathrm{K}$ & $\mathrm{Na}$ & $\mathrm{Ca}$ & $\mathrm{Mg}$ \\
\hline & $\left(1: 2 \mathrm{H}_{2} \mathrm{O}\right)$ & (\%) & (\%) & $(\mathrm{cmol} / \mathrm{kg})$ & $(\mathrm{cmol} / \mathrm{kg})$ & $(\mathrm{cmol} / \mathrm{kg})$ & $(\mathrm{cmol} / \mathrm{kg})$ & (cmol/kg) \\
\hline Phaseolus lunatus & $6.76 c$ & $1.63 b$ & $0.56 \mathrm{a}$ & $1.63 b$ & $0.61 b c$ & $0.46 b c$ & $1.53 c$ & $0.77 b$ \\
\hline TGX 199057f & $6.82 \mathrm{~b}$ & $1.29 c$ & $0.52 a$ & $1.29 c$ & $0.70 \mathrm{a}$ & $0.50 b$ & $1.41 d$ & $0.79 b$ \\
\hline TGX 198057 & $6.97 a$ & $1.72 b$ & $0.49 a$ & $1.72 b$ & $0.65 a b$ & $0.48 b c$ & $1.66 \mathrm{a}$ & $1.03 a$ \\
\hline Stylozanthes & $6.77 \mathrm{c}$ & $1.38 a$ & $0.54 a$ & $3.38 \mathrm{a}$ & $0.56 c$ & $1.94 a$ & $1.69 a$ & $0.84 b$ \\
\hline Desmodium & $6.94 a$ & $1.76 \mathrm{~b}$ & $0.54 a$ & $1.76 b$ & $0.64 a b$ & $0.45 c$ & $1.60 b$ & $0.81 b$ \\
\hline
\end{tabular}


Rhizobial inoculation had significant effect on number of nodules per plant (Table 6).Higher number of nodules was produced by Phaseolus inoculation. The Treatments imposed had significant effect on number of pods per plant (Table 6). However, the highest number of pods per plant was observed in inoculated soy bean (TGX 199057f) compared with the non-inoculated plants. The highest seed yield was obtained from soy beans (TGX 198057) that were inoculated. Desmodium produced few seeds compared to Phaseolus and Stylozanthes which did not produce any seed (Table 6).

\subsection{Interaction Effects of Legume Species, Rhizobium Inoculation and Watering Regime on Growth and Yield Parameters}

Significant interactions were obtained on growth and yield of legume species between rhizobial inoculated species and watering regime for root weight and root length. Table 7 shows that both inoculated and non-inoculated seedlings subjected to 4- and 8 -days watering intervals were consistently higher compared to inoculated and non-inoculated seedlings subjected to 12days watering interval. However, non- inoculated Phaseolus lunatus at 4-days watering interval had highest number of nodules while TGX $199057 \mathrm{f}$ non- inoculated at 8-days watering intervals had the highest value for number of pods and TGX198057 at 12 days had higher pod weight. The interaction effects of rhizobium inoculation and watering regime for plant height of legume species were significant. Species inoculated and watered at 4 and 8-days intervals were taller than those watered at 12days intervals. Consistently higher number of leaves were obtained for both the inoculated and noninoculated at 4- and 12-day intervals while plants watered at 12- days interval had lower number of leaves except for Stylozanthes that had high number of leaves in all watering regimes Table 9.

\subsection{Interaction Effects of Watering Regimes and Rhizobium Inoculation on Leaf Proximate and Chemical Composition of Legume Species}

The nitrogen, crude protein, ash, chlorophyll, soluble carbohydrates content in leaf differed among the legume species. However, legumes species inoculated and grown at 4- days watering intervals had the highest nitrogen content chlorophyll, soluble carbohydrates, ash, and moisture content compared to noninoculated legume species (Table 8). There were significant differences among the legume species for leaf proximate and chemical composition (Table 9). All the treatment gave higher effective chemical properties except for the chlorophyll content which was low in all the legume species.

\section{DISCUSSION}

\subsection{Effects of Watering Regime on Growth and Development of Legume Seedlings}

The results of this study showed that the measured growth variables of legume species responded to the watering regimes imposed. The enhancement of plant growth by more frequent watering may be attributed to higher moisture contents in the crop root zone. Hamidou et al. [27] stated that, water stress reduces plant growth through inhibition of various physiological and biochemical processes, such as photosynthesis, respiration, translocation, ion uptake, carbohydrates, nutrient metabolism, and hormones.

\subsection{Effects of Legume Species on Growth and Development as Affected by Watering Regime and Rhizobium Inoculation}

The measured growth variables of inoculated legume seedlings were statistically superior under 4- and 8 - days watering intervals compared with 12- days. This implies that the legume seedlings require consistently moist root zone environment and favourable microclimate. $[28,29]$. Legumes are known to be very sensitive to a soil water deficit $[30,31]$. Adequacy of soil moisture promotes leaf development as was obtained for seedlings that were watered 4- day possibly via enhance evapotranspiration. Adequate soil and plant water status is critical to the survival of seedlings during establishment. The results of this study confirmed that legume seedlings cannot withstand soil moisture deficit stress as was obtained for seedlings that were watered at 12- days intervals [31]. The more stressful situation of 12- days watering interval was characterized by high intensity of soil and air moisture deficits, these conditions have implications for survival and establishment of seedlings. Plants exposed to soil water deficit, exhibited number of physiological responses in an effort to conserve water. These include closing of stomata and arresting cellular growth 
[32]. If water stress is not alleviated, plants will close stomata and shut down photosynthesis, carbon assimilation, and normal metabolism [31]. These responses mean that plants experiencing water stress will end up smaller and poor in vigour [33]). Among the legume species, drought stress reduces leaf area, number of leaves and branches [34]. Rhizobium inoculation of legume seedlings significantly increased vigour of growth. Species inoculated with rhizobium recorded maximum root and shoot biomass compared to non-inoculated.

\subsection{Interaction Effects of Watering Regime and Rhizobium Inoculation on Plant Growth}

Legume seedlings inoculated with Rhizobium and subjected to different 4 day watering intervals were more vigorous going by the measured growth parameters. Nevertheless, there were no significant differences for most of the measured parameters between weeks 8 and 12 and for Rhizobium inoculated seedlings. Across the species, soya bean seedling species that were subjected to 4- day watering interval and Rhizobium inoculation have significantly $(p<$ $0.05)$ higher growth than 8 and 12 day watering regime. These findings support the observations of Levy and Rirkum [35] who reported that rhizobium inoculation increased soil water extraction and root hydraulic conductivity. Ali [23] reported that leaf development is a sensitive parameter to drought stress. In some legumes, mild water stress and rhizobium inoculation enhanced growth than the non-inoculated $[36,37]$. In conformity with the findings of the present study, Osunubi and Mulong [38] reported that rhizobium inoculation enhanced leaf number in Acacia species (A. albida and $A$. nilotica). The interaction effects between rhizobium inoculation and watering regimes was not significant on the measured (plant height, number of leaves and branches) of soya bean seedlings. Some of the measured growth parameters of soya bean seedlings in this study were promoted by rhizobium inoculation. For other parameters, the non-inoculated plants exhibited similar growth responses as the inoculated.

Table 3. Effect of rhizobium inoculation on growth parameters of Legume species

\begin{tabular}{llcll}
\hline Legume species & Rhizobium inoculation & $\begin{array}{c}\text { Plant height } \\
\text { (cm) }\end{array}$ & $\begin{array}{l}\text { Number of } \\
\text { branches }\end{array}$ & $\begin{array}{l}\text { Number of } \\
\text { leaves }\end{array}$ \\
\hline Phaseolus lunatus & Inoculated & $67.60 \mathrm{c}$ & $6.42 \mathrm{~b}$ & $35.95 \mathrm{~b}$ \\
& Non - inoculated & $39.46 \mathrm{a}$ & $12.58 \mathrm{c}$ & $25.50 \mathrm{~b}$ \\
TGX 199057f & Inoculated & $38.48 \mathrm{a}$ & $14.42 \mathrm{~b}$ & $29.33 \mathrm{a}$ \\
& Non- inoculated & $32.12 \mathrm{~b}$ & $15.25 \mathrm{a}$ & $24.33 \mathrm{~b}$ \\
TGX 198057 & Inoculated & $47.05 \mathrm{a}$ & $14.92 \mathrm{a}$ & $31.67 \mathrm{a}$ \\
& Non - inoculated & $46.56 \mathrm{~b}$ & $14.25 \mathrm{a}$ & $28.33 \mathrm{~b}$ \\
Stylozanthes & Inoculated & $40.20 \mathrm{c}$ & $15.33 \mathrm{a}$ & $29.00 \mathrm{a}$ \\
& Non - inoculated & $80.81 \mathrm{a}$ & $27.42 \mathrm{a}$ & $26.50 \mathrm{a}$ \\
Desmodium & Inoculated & $72.59 \mathrm{~b}$ & $21.75 \mathrm{~b}$ & $26.50 \mathrm{a}$ \\
& Non - inoculated & $71.02 \mathrm{~b}$ & $16.83 \mathrm{c}$ & $26.17 \mathrm{a}$ \\
\hline \multicolumn{2}{c}{ Means along the column for each legume specie bearing same letter are not significantly different by DMRT $(P=0.05)$}
\end{tabular}

Table 4. Effect of watering regimes on growth characters of legume species

\begin{tabular}{cllll}
\hline Legume species & Watering regimes & Number of leaves & No of branches & Plant height (cm) \\
\hline \multirow{3}{*}{ Phaseolus lunatus } & 4-day & $41.30 \mathrm{a}$ & $4.79 \mathrm{c}$ & $28.03 \mathrm{~b}$ \\
& 8-days & $34.94 \mathrm{a}$ & $4.56 \mathrm{c}$ & $22.68 \mathrm{~b}$ \\
& 12-days & $29.49 \mathrm{a}$ & $5.23 \mathrm{c}$ & $22.81 \mathrm{~b}$ \\
TGX 199057f & 4-days & $24.60 \mathrm{a}$ & $7.75 \mathrm{~b}$ & $28.21 \mathrm{a}$ \\
& 8-days & $23.44 \mathrm{a}$ & $7.50 \mathrm{~b}$ & $28.17 \mathrm{a}$ \\
& 12-days & $19.52 \mathrm{a}$ & $8.25 \mathrm{~b}$ & $23.96 \mathrm{ab}$ \\
TGX 198057 & 4-days & $29.80 \mathrm{a}$ & $13.79 \mathrm{~b}$ & $32.21 \mathrm{a}$ \\
& 8-days & $31.08 \mathrm{a}$ & $12.35 \mathrm{~b}$ & $23.04 \mathrm{a}$ \\
\multirow{5}{*}{ Stylozanthes } & 12-days & $25.46 \mathrm{a}$ & $11.71 \mathrm{~b}$ & $25.25 \mathrm{a}$ \\
& 4-days & $54.63 \mathrm{a}$ & $15.81 \mathrm{c}$ & $27.61 \mathrm{~b}$ \\
& 8-days & $51.35 \mathrm{a}$ & $14.94 \mathrm{~b}$ & $21.33 \mathrm{c}$ \\
Desmodium & 12-days & $54.75 \mathrm{a}$ & $11.94 \mathrm{~b}$ & $19.58 \mathrm{c}$ \\
& 4-days & $36.34 \mathrm{a}$ & $12.69 \mathrm{c}$ & $23.31 \mathrm{~b}$ \\
\multicolumn{2}{c}{ Means along the column for each legume specie bearing same letter are not significantly different by DMRT $(P=0.05)$}
\end{tabular}


Table 5. Effect rhizobium inoculation on growth and yield parameters of legume species

\begin{tabular}{|c|c|c|c|c|c|c|c|c|c|c|c|c|}
\hline Legumes species & Rhizobium & $\begin{array}{l}\text { Total } \\
\text { nodule } \\
\text { weight (g) }\end{array}$ & $\begin{array}{l}\text { No of } \\
\text { nodules }\end{array}$ & $\begin{array}{l}\text { Nodule } \\
\text { diameter } \\
(\mathrm{mm})\end{array}$ & $\begin{array}{l}\text { No of } \\
\text { pods }\end{array}$ & $\begin{array}{l}\text { Pods } \\
\text { weight }\end{array}$ & $\begin{array}{l}\text { No of } \\
\text { seeds }\end{array}$ & $\begin{array}{l}\text { Seeds } \\
\text { weight } \\
\text { (g) }\end{array}$ & $\begin{array}{l}\text { Root } \\
\text { weight } \\
\text { (g) }\end{array}$ & $\begin{array}{l}\text { Roots } \\
\text { length } \\
\text { (cm) }\end{array}$ & $\begin{array}{l}\text { Days to } \\
550 \% \\
\text { flowering }\end{array}$ & $\begin{array}{l}\text { No of } \\
\text { flowers }\end{array}$ \\
\hline Phaseolus Iunatus & Inoculated & 6.21 & 34.42 & 3.76 & 0 & 0 & 0 & 0 & 23.09 & 34.42 & 0 & 0 \\
\hline TGX 199057f & & 0.65 & 2.27 & 0.85 & 16.8 & 6.69 & 28.71 & 4.24 & 2.75 & 30.5 & 18.92 & 15.82 \\
\hline TGX 198057 & & 0.57 & 1.13 & 2.24 & 18.11 & 8.48 & 40.45 & 7.18 & 1.96 & 31.81 & 28.38 & 17.94 \\
\hline Stylozanthes & & 0 & 0 & 0 & 0 & 0 & 0 & 0 & 5.06 & 20.06 & 0 & 4.89 \\
\hline \multirow{2}{*}{ Desmodium } & & 0 & 0 & 0 & 0 & 0 & 224.44 & 1.63 & 27.24 & 38.66 & 61.66 & 17.62 \\
\hline & LSD & 0.32 & 0.54 & 0.23 & 1.1 & 0.32 & 6.12 & 0.12 & 1.1 & 4.6 & 4.21 & 2.12 \\
\hline Phaseolus Iunatus & Non- & 3.43 & 8.26 & 2.48 & 0 & 0 & 0 & 0 & 19.08 & 36.7 & 0 & 0 \\
\hline TGX $199057 f$ (Soya bean) & inoculated & 0 & 0.32 & 0.07 & 23.49 & 7.01 & 36.54 & 4.73 & 0.5 & 22.84 & 19.9 & 15.33 \\
\hline TGX 198057(soya bean) & & 0.16 & 0.32 & 0.67 & 21.53 & 3.79 & 28.06 & 5.87 & 2.25 & 34.25 & 29.36 & 13.21 \\
\hline Stylozanthes & & 0 & 0 & 0 & 0 & 0 & 0 & 0 & 5.22 & 15.33 & 0 & 1.96 \\
\hline \multirow[t]{2}{*}{ Desmodium } & & 0 & 0 & 0 & 0 & 0 & 112.71 & 0.98 & 13.54 & 35.4 & 67.85 & 15.17 \\
\hline & LSD & 4.49 & 1.3 & 0.73 & 2.53 & 0 & 20.14 & 4.48 & 3.12 & 8.89 & 9.08 & 1.47 \\
\hline
\end{tabular}

Table 6. Effect of watering regimes on growth and yield parameters of legume species

\begin{tabular}{|c|c|c|c|c|c|c|c|c|c|c|c|c|}
\hline Legumes species & $\begin{array}{l}\text { Watering } \\
\text { regimes }\end{array}$ & $\begin{array}{l}\text { Root } \\
\text { weight } \\
\text { (g) }\end{array}$ & $\begin{array}{l}\text { Root } \\
\text { length } \\
\text { (cm) }\end{array}$ & $\begin{array}{l}\text { Pod } \\
\text { weight } \\
\text { (g) }\end{array}$ & $\begin{array}{l}\text { No of } \\
\text { pods }\end{array}$ & $\begin{array}{l}\text { Seeds } \\
\text { weight } \\
\text { (g) }\end{array}$ & $\begin{array}{l}\text { No of } \\
\text { seeds }\end{array}$ & $\begin{array}{l}\text { Days to } \\
50 \% \\
\text { flowering }\end{array}$ & $\begin{array}{l}\text { No of } \\
\text { flowers }\end{array}$ & $\begin{array}{l}\text { Total } \\
\text { nodule } \\
\text { weight(g) }\end{array}$ & $\begin{array}{l}\text { Nodule } \\
\text { diameter } \\
\text { (cm) }\end{array}$ & $\begin{array}{l}\text { No of } \\
\text { nodules }\end{array}$ \\
\hline \multirow{3}{*}{ Phaseolus lunatus } & 4-days & $31.37 a$ & $40.13 a$ & 0 & 0 & 0 & 0 & 0 & 0 & $7.35 a$ & $3.77 a$ & $16.28 a$ \\
\hline & 8-days & $12.56 \mathrm{~b}$ & $34.25 a$ & 0 & 0 & 0 & 0 & 0 & 0 & $4.89 b$ & $3.33 a$ & $9.23 b$ \\
\hline & 12-days & $19.33 c$ & $32.3 a$ & 0 & 0 & 0 & 0 & 0 & 0 & $2.2 \mathrm{c}$ & $2.27 b$ & $7.78 b$ \\
\hline \multirow{3}{*}{ TGX 199057f (Soya bean) } & 4-days & $0.98 a$ & $34.25 a$ & $6.85 a$ & $18.59 a$ & $4.89 a$ & $38.17 a$ & 0 & $14.68 \mathrm{a}$ & 0 & $0.59 a$ & $0.97 a$ \\
\hline & 8-days & $0.99 a$ & $28.14 b$ & $6.85 a$ & $19.33 b$ & $4.16 b$ & $30.34 b$ & $28.38 \mathrm{~b}$ & $16.88 \mathrm{~b}$ & $0.98 a$ & $0.73 b$ & $2.43 b$ \\
\hline & 12-days & $2.91 c$ & $17.62 \mathrm{c}$ & $6.85 a$ & $22.51 c$ & $4.4 \mathrm{c}$ & $29.36 c$ & $29.85 b$ & $15.17 \mathrm{c}$ & 0 & $0.05 c$ & $0.49 c$ \\
\hline \multirow{3}{*}{ TGX 198057 (Soya bean) } & 4-days & $0.98 a$ & $34.25 a$ & $6.85 a$ & $18.59 a$ & $4.89 a$ & $38.17 a$ & 0 & $14.68 a$ & 0 & $0.59 a$ & $0.97 a$ \\
\hline & 8-days & $1.27 b$ & $40.86 b$ & $9.54 b$ & $20.8 b$ & $5.38 \mathrm{~b}$ & $34.74 b$ & $28.38 \mathrm{~b}$ & $16.15 b$ & 0 & 0 & 0 \\
\hline & 12-days & $1.22 \mathrm{~b}$ & $24.96 c$ & $8.81 \mathrm{c}$ & $21.04 b$ & $6.36 c$ & $36.21 b$ & $28.38 \mathrm{~b}$ & $21.04 \mathrm{~b}$ & 0.37 & $1.22 \mathrm{~b}$ & $0.73 b$ \\
\hline \multirow[t]{3}{*}{ Stylozanthes } & 4-days & $7.34 a$ & $19.08 \mathrm{a}$ & 0 & 0 & 0 & 0 & 0 & 0 & 0 & 0 & 0 \\
\hline & 8-days & $3.67 b$ & $19.82 \mathrm{ac}$ & 0 & 0 & 0 & 0 & 0 & 0 & 0 & 0 & 0 \\
\hline & 12-days & $4.4 \mathrm{c}$ & $14.19 a$ & 0 & 0 & 0 & 0 & 0 & 0 & 0 & 0 & 0 \\
\hline \multirow{3}{*}{ Desmodium } & 4-days & $25.2 a$ & $29.85 a$ & 0 & 0 & $1.1 \mathrm{a}$ & $172.73 a$ & $64.1 \mathrm{a}$ & 0 & 0 & 0 & 0 \\
\hline & 8-days & $17.62 b$ & $40.13 b$ & 0 & 0 & $1.35 b$ & 181.3b & $64.1 \mathrm{a}$ & 0 & 0 & 0 & 0 \\
\hline & 12-days & $18.35 c$ & $41.1 \mathrm{~b}$ & 0 & 0 & $1.47 \mathrm{c}$ & $151.69 \mathrm{c}$ & $66.06 c$ & 0 & 0 & 0 & 0 \\
\hline
\end{tabular}


Agele et al.; IJPSS, 17(4): 1-15, 2017; Article no.IJPSS.32891

Table 7. Interaction effects of rhizobium inoculation and watering regimes on growth and yield parameter of legume species

\begin{tabular}{|c|c|c|c|c|c|c|c|c|c|c|c|c|}
\hline Legume species & $\begin{array}{l}\text { Rhizobium } \\
\text { inoculation }\end{array}$ & $\begin{array}{l}\text { Watering } \\
\text { Regimes }\end{array}$ & $\begin{array}{l}\text { No of } \\
\text { nodules }\end{array}$ & $\begin{array}{l}\text { Total no } \\
\text { nodules } \\
\text { (g) }\end{array}$ & $\begin{array}{l}\text { Root } \\
\text { length } \\
\text { (cm) }\end{array}$ & $\begin{array}{l}\text { Pod } \\
\text { weight } \\
\text { (g) }\end{array}$ & $\begin{array}{l}\text { No of } \\
\text { pods }\end{array}$ & $\begin{array}{l}\text { No of } \\
\text { leaves }\end{array}$ & $\begin{array}{l}\text { No of } \\
\text { seeds }\end{array}$ & $\begin{array}{l}\text { Seed } \\
\text { weight }(g)\end{array}$ & $\begin{array}{l}\text { Root } \\
\text { weight } \\
\text { (g) }\end{array}$ & $\begin{array}{l}\text { Days to } \\
50 \% \\
\text { flowering }\end{array}$ \\
\hline \multirow{7}{*}{ Phaseolus lunatus } & Inoculated & 4 -days & 12.15 & 6.39 & 29.36 & 0 & 0 & 48.27 & 0 & 0 & 34.35 & 0 \\
\hline & & 8-days & 18.47 & 9.79 & 34.25 & 0 & 0 & 42.28 & 0 & 0 & 16.8 & 0 \\
\hline & & 12-days & 11.18 & 2.45 & 39.64 & 0 & 0 & 37.14 & 0 & 0 & 18.11 & 0 \\
\hline & Non inoculated & 4-days & 20.41 & 8.32 & 50.89 & 0 & 0 & 34.32 & 0 & 0 & 28.38 & 0 \\
\hline & & 8-days & 0 & 0 & 34.25 & 0 & 0 & 27.6 & 0 & 0 & 8.32 & 0 \\
\hline & & 12 -days & 4.37 & 1.96 & 24.96 & 0 & 0 & 21.85 & 0 & 0 & 20.55 & 0 \\
\hline & LSD & & 1.41 & 1.94 & 0.53 & & & 10.4 & & & & 1.94 \\
\hline \multirow[t]{7}{*}{ TGX 199057f } & Inoculated & 4-days & 0.97 & 0 & 48.44 & 9.3 & 16.64 & 27.6 & 43.06 & 5.38 & 1.47 & 0 \\
\hline & & 8-days & 4.86 & 1.96 & 23.49 & 4.4 & 15.66 & 25.76 & 22.51 & 3.43 & 1.47 & 28.38 \\
\hline & & 12-days & 0.97 & 0 & 19.57 & 6.36 & 18.11 & 22.34 & 20.55 & 3.92 & 5.32 & 28.38 \\
\hline & Non inoculated & 4-days & 0.97 & 0 & 20.06 & 4.4 & 20.55 & 21.6 & 33.28 & 4.4 & 0.49 & 0 \\
\hline & & 8-days & 0 & 0 & 32.79 & 9.3 & 23 & 21.11 & 38.17 & 4.89 & 0.51 & 28.38 \\
\hline & & 12-days & 0 & 0 & 15.66 & 7.34 & 26.91 & 16.71 & 38.17 & 4.89 & 0.49 & 31.32 \\
\hline & LSD & & 0.44 & 1.1 & 0.66 & 1.1 & 0.66 & 13.5 & 1.1 & 0.44 & 0.66 & 1.1 \\
\hline \multirow[t]{7}{*}{ TGX 198057} & Inoculated & 4-days & 1.94 & 0.98 & 36.7 & 9.79 & 17.13 & 31.76 & 56.76 & 10.77 & 2.94 & 28.38 \\
\hline & & 8-days & 0 & 0 & 34.25 & 8.81 & 19.08 & 34.08 & 33.28 & 5.38 & 1.47 & 28.38 \\
\hline & & 12-days & 1.46 & 0.73 & 24.47 & 6.85 & 18.11 & 27.11 & 31.32 & 5.38 & 1.47 & 28.38 \\
\hline & Non inoculated & 4-days & 0.97 & 0.49 & 29.85 & 8.32 & 18.11 & 27.84 & 6.85 & 4.89 & 4.7 & 31.32 \\
\hline & & 8-days & 0 & 0 & 47.47 & 10.28 & 22.51 & 28.09 & 36.21 & 5.38 & 1.08 & 28.38 \\
\hline & & 12-days & 0 & 0 & 25.45 & 10.77 & 23.98 & 23.8 & 41.1 & 7.34 & 0.98 & 28.38 \\
\hline & LSD & & 0.68 & 0.79 & 0.1 & 0.78 & 0.1 & 15.4 & 0.78 & 0.68 & 0.1 & 0.78 \\
\hline \multirow{7}{*}{ Stylozanthes } & Inoculated & 4-days & 0 & 0 & 22.02 & 0 & 0 & 68.09 & 0 & 0 & 4.89 & 0 \\
\hline & & 8-days & 0 & 0 & 23.49 & 0 & 0 & 63.37 & 0 & 0 & 4.89 & 0 \\
\hline & & 12-days & 0 & 0 & 14.68 & 0 & 0 & 72.37 & 0 & 0 & 5.38 & 0 \\
\hline & Non inoculated & 4 -days & 0 & 0 & 16.15 & 0 & 0 & 41.17 & 0 & 0 & 9.79 & 0 \\
\hline & & 8-days & 0 & 0 & 16.15 & 0 & 0 & 39.34 & 0 & 0 & 2.45 & 0 \\
\hline & & 12-days & 0 & 0 & 13.7 & 0 & 0 & 37.14 & 0 & 0 & 3.43 & 0 \\
\hline & LSD & & - & - & 0.14 & - & - & 17.2 & - & - & 0.14 & - \\
\hline \multirow[t]{7}{*}{ Desmodium } & Inoculated & 4-days & 0 & 0 & 34.25 & 0 & 0 & 42.15 & 222.65 & 1.47 & 35.23 & 59.7 \\
\hline & & 8-days & 0 & 0 & 40.62 & 0 & 0 & 40.56 & 247.6 & 1.47 & 23.98 & 61.66 \\
\hline & & 12-days & 0 & 0 & 41.1 & 0 & 0 & 34.32 & 203.07 & 1.96 & 22.51 & 63.61 \\
\hline & Non inoculated & 4-days & 0 & 0 & 25.45 & 0 & 0 & 30.53 & 122.82 & 0.73 & 15.17 & 68.51 \\
\hline & & 8-days & 0 & 0 & 39.64 & 0 & 0 & 35.92 & 114.99 & 1.22 & 11.26 & 66.55 \\
\hline & & 12-days & 0 & 0 & 41.1 & 0 & 0 & 34.45 & 100.31 & 0.98 & 14.19 & 68.51 \\
\hline & LSD & & & & 0.68 & & & 9.4 & 1.46 & 0.78 & 0.68 & 1.46 \\
\hline
\end{tabular}


Agele et al.; IJPSS, 17(4): 1-15, 2017; Article no.IJPSS.32891

Table 8. Interaction effect of watering regime and rhizobium inoculation on leaf proximate chemical composition of legumes species

\begin{tabular}{|c|c|c|c|c|c|c|c|c|c|}
\hline Legume species & $\begin{array}{l}\text { Inoculation } \\
\text { or not }\end{array}$ & $\begin{array}{l}\text { Watering } \\
\text { Regimes }\end{array}$ & $\begin{array}{l}\text { Soluble carbohydrate } \\
(\mathrm{mg} / \mathrm{kg})\end{array}$ & $\begin{array}{l}\text { Moisture } \\
\text { content (\%) }\end{array}$ & $\begin{array}{l}\text { Chlorophyll } \\
\text { (mg/kg) }\end{array}$ & $\begin{array}{l}\text { Ash } \\
(\%)\end{array}$ & $\begin{array}{l}\text { Crude } \\
\text { fibre (\%) }\end{array}$ & $\begin{array}{l}\text { Crude } \\
\text { protein (\%) }\end{array}$ & Nitrogen (\%) \\
\hline \multirow{7}{*}{ Phaseolus lunatus } & \multirow{3}{*}{ Inoculated } & 4 - days & 12.52 & 63.98 & 0.06 & 3.09 & 5.70 & 35.64 & 5.71 \\
\hline & & 8 - days & 12.48 & 64.88 & 0.12 & 4.27 & 5.36 & 33.51 & 5.36 \\
\hline & & 12 - days & 11.2 & 59.42 & 0.07 & 1.33 & 5.08 & 31.78 & 5.18 \\
\hline & \multirow[t]{3}{*}{ Non-inoculated } & 4 - days & 11.92 & 50.26 & 0.03 & 2.99 & 4.73 & 29.57 & 4.73 \\
\hline & & 8 - days & 13.48 & 64.15 & 0.09 & 1.96 & 4.51 & 28.2 & 4.51 \\
\hline & & 12 - days & 11.69 & 60.52 & 0.09 & 2.96 & 4.62 & 28.9 & 4.62 \\
\hline & LSD & & 0.88 & 62.38 & 0.88 & 1.38 & 0.08 & 0.49 & 0.18 \\
\hline \multirow[t]{7}{*}{ TGX 199057f } & \multirow[t]{3}{*}{ Inoculated } & 4 - days & 13.01 & 64.86 & 0.05 & 1.23 & 4.50 & 28.14 & 3.91 \\
\hline & & 8 - days & 11.94 & 48.24 & 0.07 & 2.5 & 3.92 & 24.5 & 3.86 \\
\hline & & 12 - days & 11.92 & 71.08 & 0.05 & 2.08 & 3.90 & 24.35 & 3.87 \\
\hline & \multirow{3}{*}{ Non -inoculated } & 4 - days & 12.15 & 65.01 & 0.07 & 3.41 & 3.66 & 22.9 & 3.66 \\
\hline & & 8 - days & 10.32 & 64.67 & 0.05 & 2.37 & 3.49 & 21.83 & 3.49 \\
\hline & & 12 - days & 8.72 & 59.27 & 0.03 & 4.89 & 3.44 & 21.53 & 3.44 \\
\hline & LSD & & 2.25 & 66.52 & 2.25 & 1.37 & 0.11 & 0.69 & 1.38 \\
\hline \multirow[t]{7}{*}{ TGX 198057} & \multirow[t]{3}{*}{ Inoculated } & 4 - days & 14.96 & 69.05 & 0.26 & 3.14 & 6.11 & 38.16 & 6.1 \\
\hline & & 8 - days & 14.2 & 63.98 & 0.07 & 3.05 & 5.83 & 36.46 & 5.83 \\
\hline & & 12 - days & 13.05 & 64.88 & 0.05 & 3.56 & 5.78 & 36.1 & 5.78 \\
\hline & \multirow[t]{3}{*}{ Non-inoculated } & 4 - days & 12.53 & 59.42 & 0.05 & 2.31 & 4.48 & 28.03 & 4.47 \\
\hline & & 8 - days & 11.44 & 50.26 & 0.06 & 2.79 & 4.49 & 28.04 & 4.49 \\
\hline & & 12 - days & 15.38 & 64.15 & 0.07 & 1.51 & 4.49 & 28.08 & 4.74 \\
\hline & LSD & & 0.88 & 60.52 & 0.88 & 1.56 & 0.08 & 0.49 & 1.37 \\
\hline \multirow{7}{*}{ Stylozanthes } & \multirow[t]{3}{*}{ Inoculated } & 4 - days & 13.66 & 62.38 & 0.07 & 2.82 & 6.44 & 40.25 & 6.44 \\
\hline & & 8 - days & 12.7 & 64.86 & 0.04 & 3.27 & 6.62 & 41.4 & 6.62 \\
\hline & & 12 - days & 11.7 & 48.24 & 0.07 & 3.17 & 6.65 & 41.56 & 6.64 \\
\hline & \multirow[t]{3}{*}{ Non -inoculated } & 4 - days & 12.67 & 71.08 & 0.12 & 2.01 & 7.69 & 48.04 & 7.68 \\
\hline & & 8 - days & 11.91 & 65.01 & 0.03 & 2.02 & 6.87 & 42.92 & 6.86 \\
\hline & & 12 - days & 13.63 & 64.67 & 0.07 & 1.67 & 7.67 & 47.92 & 7.66 \\
\hline & LSD & & 0.68 & 59.27 & 0.68 & 0.18 & 0.11 & 0.69 & 1.56 \\
\hline \multirow[t]{7}{*}{ Desmodium } & \multirow[t]{3}{*}{ Inoculated } & 4 - days & 12.95 & 66.52 & 0.07 & 3.02 & 5.09 & 31.81 & 5.07 \\
\hline & & 8 - days & 11.83 & 69.05 & 0.04 & 2.81 & 5.01 & 31.31 & 5 \\
\hline & & 12 - days & 12.49 & 63.98 & 0.08 & 2.53 & 5.09 & 31.81 & 5.09 \\
\hline & \multirow[t]{4}{*}{ Non-inoculated } & 4 - days & 12.87 & 64.88 & 0.08 & 2.07 & 5.09 & 31.84 & 6.32 \\
\hline & & 8 - days & 10.78 & 59.42 & 0.05 & 2.56 & 5.03 & 31.42 & 5.02 \\
\hline & & 12 - days & 11.28 & 50.26 & 0.04 & 2.64 & 5.01 & 31.34 & 5.01 \\
\hline & & LSD & 6.45 & 64.15 & 6.45 & 1.98 & 0.11 & 0.66 & 0.48 \\
\hline
\end{tabular}


Table 9. The leaf proximate and chemical composition of Legume species

\begin{tabular}{|c|c|c|c|c|c|c|c|c|c|c|c|c|c|c|c|c|c|c|c|}
\hline \multirow[b]{2}{*}{ Legumes species } & \multicolumn{3}{|c|}{$\begin{array}{c}\text { Water soluble } \\
\text { carbohydrate (\%) }\end{array}$} & \multicolumn{3}{|c|}{$\begin{array}{c}\text { Chlorophyll } \\
(\mathrm{mg} / \mathrm{kg})\end{array}$} & \multicolumn{3}{|c|}{ Ash (\%) } & \multicolumn{3}{|c|}{ Moisture content (\%) } & Crude fibre (\%) & \multicolumn{3}{|c|}{ Crude protein (\%) } & \multicolumn{3}{|c|}{ Nitrogen (\%) } \\
\hline & $4^{*}$ & $8^{*}$ & $12^{*}$ & 4 & 8 & 12 & 4 & 8 & 12 & 4 & 8 & 12 & 12 & 4 & 8 & 12 & 4 & 8 & 12 \\
\hline Phaseolus lunatus & $12.22^{c}$ & 12.98 & $11.45^{\mathrm{c}}$ & $0.05^{b}$ & $0.10^{\mathrm{a}}$ & $0.10^{\mathrm{a}}$ & $2.70^{\mathrm{a}}$ & $3.65^{\mathrm{a}}$ & $2.07^{b}$ & $63.98^{\mathrm{b}}$ & $64.88^{\mathrm{a}}$ & $59.42^{\mathrm{a}}$ & $5.14^{c} 6.01^{b} 6.60^{a}$ & $32.60^{b}$ & $30.85^{\mathrm{b}}$ & $30.34^{b}$ & $5.22^{b}$ & $4.93^{b}$ & $4.90^{\mathrm{C}}$ \\
\hline TGX $199057 f$ & $12.58^{\mathrm{C}}$ & 11.13 & $10.32 d$ & $0.05^{b}$ & $0.07^{\mathrm{b}}$ & $0.08^{b}$ & $1.88^{b}$ & $2.74^{\mathrm{b}}$ & $2.02^{b}$ & $50.26^{\mathrm{C}}$ & $64.15^{\mathrm{a}}$ & $60.52^{\mathrm{a}}$ & $6.76^{b} 7.02^{a} 5.95^{a}$ & $25.52^{\mathrm{C}}$ & $23.17^{\mathrm{C}}$ & $22.94^{\mathrm{C}}$ & $3.79^{c}$ & $3.67^{c}$ & $3.65^{c}$ \\
\hline TGX 198057 & $13.75 a$ & 12.82 & $14.21^{a}$ & $0.06^{b}$ & $0.15^{\mathrm{a}}$ & $0.05^{b}$ & $3.19^{a}$ & $2.58^{b}$ & $2.32^{b}$ & $62.38^{\mathrm{b}}$ & $64.86^{\mathrm{a}}$ & $48.24^{b}$ & $6.73^{b} 6.83^{b} 5.63^{a}$ & $33.09^{b}$ & $32.25^{\mathrm{b}}$ & $32.09^{b}$ & $5.28^{b}$ & $5.16^{b}$ & $5.26^{b}$ \\
\hline Stylozanthes & $13.16 \mathrm{~b}$ & 12.3 & $12.66^{\mathrm{b}}$ & $0.05^{b}$ & $0.09^{\mathrm{a}}$ & $0.05^{b}$ & $2.53^{a}$ & $2.79^{b}$ & $2.24^{a}$ & $71.08^{\mathrm{a}}$ & $65.01^{a}$ & $64.67^{\mathrm{a}}$ & $7.01^{\mathrm{a}} 7.70^{\mathrm{a}} 6.85^{\mathrm{a}}$ & $44.14^{\mathrm{a}}$ & $42.16^{\mathrm{a}}$ & $44.74^{a}$ & $7.06^{\mathrm{a}}$ & $6.74^{\mathrm{a}}$ & $7.15^{\mathrm{a}}$ \\
\hline Desmodium & $12.91^{\mathrm{c}}$ & 11.31 & $11.89^{\mathrm{C}}$ & $0.07^{\mathrm{a}}$ & $0.03^{\mathrm{c}}$ & $0.06^{b}$ & $2.67^{a}$ & $2.87^{b}$ & $3.77^{\mathrm{a}}$ & $59.27^{b}$ & $66.52^{\mathrm{a}}$ & $69.05^{\mathrm{a}}$ & $6.93^{b} 6.21^{b} 6.76^{a}$ & $31.82^{b}$ & $31.36^{\mathrm{b}}$ & $31.57^{\mathrm{b}}$ & $5.69^{b}$ & $5.01^{b}$ & $5.05^{\mathrm{b}}$ \\
\hline
\end{tabular}


The highest pod weight, seed weight number of seed per pod, number of nodule, nodule weight was obtained from inoculated species which was significantly higher than non-inoculated species. This result is in agreement with Shu-Jie et al. [39] who reported similar findings and concluded that the number of pods per plant, seeds per pod, and seed yield were significantly increased by different phosphorus levels. This may be attributed to the symbiotic relationship of rhizobia (bacteria) with the roots of leguminous crops, which fixes atmospheric nitrogen into the roots of legumes and thus the yield increased. This is in agreement with Stefanescu and Palansiuc [40] who reported that phosphorus and rhizobium inoculation induced a pronounced effect on yield. The authors inferred that number of pods per plant, seeds per pod, 100 grain weight and seed yield were significantly increased by different phosphorus levels.

The improvement of nodulation by rhizobium inoculation resulted in higher nitrogen fixation (Table 2) and consequently increased in vegetative growth yield of Desmodium when compared to the non-inoculated species. The results of present study are in conformity with observations made by Lawson and Quainoo [4143] that non-inoculated plants produced decreased vegetative growth when compared to non- inoculated ones.

\section{CONCLUSIONS}

The effects of watering regime and rhizobial inoculation on the growth, nodulation and seed yield of some legume species: the staple; Legume Soybean (TGX 199057f' and TGX198057) and forage legume species; Stylozanthes and Desmodium was evaluated. The legume species differed significantly in their responses to watering regimes and rhizobial inoculation based on the measured growth parameters. Seedlings that were watered at 4 and 8 days interval were more vigorous in growth compared to 12 days watering intervals. Rhizobium inoculated legumes produced more root nodule and number of leaves and taller plants compared with the non-inoculated species. The highest number of leaves and root nodules were produced by inoculated Phaseolus lunatus. Compared with 12- days watering interval, both inoculated and non-noculated seedlings subjected to 4- and 8- days watering intervals had higher root and shoot biomass. The non- inoculated TGX $199057 \mathrm{f}$ watered at 8- days intervals had the highest number of pods while
TGX198057 watered at 12 days had higher pod weight. Highest seed yield was obtained from soybean (TGX 198057) that were inoculated. Desmodium produced few seeds compared to Phaseolus lunatus and Styolzanthes across the watering regimes imposed. Rhizobium inoculation and 4- and 8- days watering intervals enhanced vigour of growth compared with 12days watering. The effects of watering regimes and rhizobium inoculation varied on leaf proximate and chemical composition of legume species. The nitrogen, crude protein, ash, chlorophyll, soluble carbohydrates content in leaf differed among the legume species. The legume species inoculated and grown at 4- days watering intervals had the highest nitrogen content chlorophyll, soluble carbohydrates, ash, and moisture content compared to noninoculated legume species. Application of rhizobium strain significantly increased seed yield of soybean and Desmodium and caused substantial increase in nodulation. Rhizobial inoculation will affect the $\mathrm{N}_{2}$ fixation potential of the legumes under varying soil moisture regimes in the legume species. Based on the measured growth parameters in this study, rhizobium inoculation and 4- and 8- days watering intervals promoted plant vigour compared with 12- days watering interval. The study has shown that to increase legume productivity, application of rhizobium inoculant is recommended.

\section{COMPETING INTERESTS}

Authors have declared that no competing interests exist.

\section{REFERENCES}

1. Giller KE, Cadisch G. Future benefits from biological Nitrogen fixation: An ecological approach to agriculture. Plant and Soil. 1995;174:255-277.

Available:http://dx.doi.org/10.1007/BF0003 $\underline{2251}$

2. Food and Agricultural Organization (FAO). Definition and classification of commodities; Pulses and derived products. FAO Rome; 2014.

3. Kanyama Phiri EY. Response of Desmodium intortum and Centrosema pubescens to soil moisture stress. The first conference of the african association for biological nitrogen fixation, Nairobi, Kenya; 1984.

4. De L Leeuw PN. Mohamed-Saleem MA. Salati E. Stylozanthes as a forage and 
fallow crop. International Livestock Center for Africa, Addis Ababa, Ethopia; 1994.

5. Spren EM, Scher-Lorensen M. Schmid B, Hector A, Caldiera MC, Dimitrakopoulos $P G$, Finn JAJ. Umpponen A. O'Donnovan G, Pereria JS. The role of legume as a component of biodiversity in a cross European study of grass land biomass nitrogen. Oilkos. 2002;98:205-218.

6. Bagayoko M. Buerkert A. Lung G. Bationo $A$, Romheld V. Cereal/legume rotation effects on cereals growth on SudanoSahelian West Africa: Soil mineral nitrogen, rhizobium and nematodes. Plant and Soil. 2000;218:103-16.

7. Date RA, Halliday J. Relationship between rhizobium and tropical forage legumes. In: Summerfield RJ, Bunting AA, (Eds.). Advance in legume sciences. Royal Botanical Gardens, Kew. 1980;597-601.

8. De Faria SM, Lewis GP, Sprent JI, Sutherland JM. Occurrence of nodulation in the leguminosae. New Phytology. 1989;111:607-619.

9. Lindermann WC. Soil microbiologist college of agriculture, consumer and enviromental sciences. New Mexico State University, USA; 2015.

10. Hoyt GD, Hargrove WH. Legume cover crops for improving crop and soil management in the southern United States. Horticultural Science. 1986;21:397402.

11. Graham PH, Vance CP. Legumes: importance and constraints to greateruse. Plant Physiology. 2000;131:872-8771.

12. Ahmed Zl, Ansar M, Tariq B, Anjum MS. Effect of different Rhizobium inoculation methods on performance of lentil in Pothowar region. International Journal of Agriculture and Biology. 2008;10:81-84.

13. Chaves MM, Pereira JS, Maroco J, Rodrigues ML, Recado CPP, Osorio ML. How plants cope with water stress in the field. Photosynthesis and growth. Annals of Botany. 2002;89:907-916.

14. Pandy RK. Herrera WAT, Pendleton JW. Drought response of grain legumes under irrigation gradient: Yield and yield components. Agronomy Journal. 1984; 76(4):549-53.

15. Graham PH. Stress tolerance in Rhizobium and Bradyrhizobium and nodulation under adverse soil condition. J. Microbiol. 2002; 135:375-485.

16. Nunes C. de Souse Araiyo S. da Silva JM. Fevererio MD. Da Slivar AB. Physiology responses of the legume model Medicago truncatula Cvr Jem along to water deficit. Enviromental and Experiment Botany. 2008;63:289-96.

17. Kennedy IR, Cockings EC. Biological Nitrogen Fixation: The global challenge and future needs. Rockefeller foundation bellagion conference proceedings. SUN Fix Press, University of Sydney, Australia. 1997;83.

18. Giller KE. Nitrogen fixation in tropical cropping systems. CABI Publishing, Wallingford, UK; 2001.

19. Glover CR, Lindemann WC. Nitrogen fixation by legumes. New Mexico State Univ. Coop. Ext. Serv. Guide A-129. New Mexico State University, USA; 2003.

20. Jim Deacon T. The nitrogen cycle and Nitrogen fixation, Institute of cell and molecular biology, The university of Edinburgh, Edinburgh, Scotland; 1998

21. Vadez V, Rao S, Kholova J, Krishnamurthi L, Kashuoagi J. Ratinakumar P. Root research for drought tolerance in legume: Quovadis? Journal of Food legumes. 2008;21(2):77-85.

22. Serraj R, Sinclair TR, Purcell LC. Symbiotic $\mathrm{N}_{2}$ fixation response to drought. Journal of Experimental Botany. 1999;23: 15-21.

23. Ali MA, Hussain MW, Malik H, Tahir M. Evaluation of the effect of Rhizobium inoculation and phosphorus, grain yield and nodulation behaviour. Pakistan Journal of Life Science. 2004;22:112-114.

24. Okereke GU. Onochie C. Onunkwo A. Onyeagba E. Effectiveness of foreign Brady rhizobia strains in enhancing nodulation, dry matter and seed yield of soybean (Glycine max L.) cultivars in Nigeria. Biology and Fertility of Soils. 2004; 33:3-9.

Available:http://dx.doi.org/10.1007/s00374 0000264

25. Karou M, Oweis T. Water and land productivities of wheat and food legumes with deficit supplemental irrigation in a Mediterrnean environment. Agricultural Water Management. 2012;107:94-103.

26. Oya T, Nepomuceno AL, Neumaier N, Faris JRB, Tobitas S, Ito O. Drought tolerance characteristics of Brazilian soybean cultivars: Evaluation and characterization of drought tolerance of various Brazilian soybean cultivars in the field. Plant Production Science. 2004; 27(2):129-37. 
27. Hamidou F, Zombre G, Braconnier S. Physiological and biochemical responses of cowpea genotype to water stress under glasshouse and field conditions. Journal of Agronomy and Crop Science 2007;193: 229-237.

28. Henson IE, Harun $\mathrm{MH}$, Chang $\mathrm{KC}$, Mohammed AT. Predicting soil water status, evapotranspiration growth and yield of young oil palm in a seasonally dry region of Malaysia. Journal of Oil Palm Research. 2007;19:398-415.

29. Eaglesham A, Seaman B, Ahmed $H$, Hassoumas T. Ayanba A, Mulongoy K. High temperature tolerant cowpea rhizobia In: Current perspectives in nitrogen fixation. (Gibson $\mathrm{AH}$, Newton WE Eds.) Australian Academy of Science, Canberra. $1981 ; 436$.

30. Jafer MS, Slam MHE, Amir ASR, Ghorban $\mathrm{N}$, Ghasem Z.The effects of water deficit during growth stage of canola (Brassic canapus L.). America-Eurasian Journal Agricultural and Enviromental Sciences. 2007;2(4):417-422.

31. Kulac SP. Nzokou D, Guney D, Gregg BM, Turna I. Growth and physiological response of fraser fir [Abiesfraseri (Pursh) Poir.] seedlings to water stress: Seasonal and diurnal variations in photosynthetic pigments and carbohydrate concentration. Hort Science. 2012;47(10):1512-1519.

32. Jones HG, Tardieu F. Modelling (sic) water relations of horticultural crops: A review. Scientia Horticulturae. 1997;74:21-46.

33. Lawson IYD, Quainoo A. Response of soybean to organic matter application and inoculation with Bradyrhizobium japonicum in the Guinea savanna of Ghana. Journal of the Ghana Science Association. 2008;4(1):53-57.

34. Levy Y, Kirkum J. Effect of irrigation, water and salinity and root-stock on the vertical distribution of Rhizobium bacteria on citrus roots. New Phytopathology. 1983;15:397403.

35. Read DJ, Boyd RC. Water relations of Rhizobium and their host plant in (Ayres PC, Boddy L, Eds.). Water, bacteria and plants. Cambridge University Press, Cambridge U.K; 1986.

36. Yucel DO, Anlarsal AE, Mart DF, Yucel C. Effects of drought stress on early seedlings growth of chickpea (Cicer arietinum) genotypes. World Application Science Journal. 2010;11(4):478-485.

37. Dashti N, Zhang F, Hynes R, Smith DL. Application of plant growth promoting rhizobacteria to soybean (Glycine max (L.) Merr.) increases protein and dry matter yield under short season conditions. Plant Soil. 1995;188:33-41.

Available:http://dx.doi.org/10.1023/A:10042 95827311

38. Osunubi O, Mulongony K. Interaction between drought stress and vesicular Arbuscular mycorrhizal on growth of Faidherbia albida (Acacia albida) and Acacia niloticain sterile and non-sterile soils. Biology and Fertility of Soils. 1992;3:159-165.

39. Shu-Jie M, Yun-Fa Q, Xiao-Zeng $H$, An M. Nodule formation and development in soybeans (Glycine mux L.) in response to phosphorus supply in solution culture. Pedosphere. 2007;17:36-43.

Available:http://dx.doi.org/10.1016/S10020160(07)60005-8

40. Stefanescu M, Palanciuc V. Efficiency of bacterial inoculation and mineral nitrogen and phosphorus fertilization in rainfed soybean. Roma Agric. Res. 2000;13-14: 75-83.

41. Peterson PR, Herrera WAT, and Pendle JW. Drought effects on perennial forage legume yield and quality. Agronomy Journal. 1992;81(5):774-9.

42. Dennis EA. Nodulation and nitrogen fixation in legumes of the tropics. London. In Biological nitrpogen fixation in farming systems of the tropics. (Anyanaba A and Dart P eds.) John Wiley, London. 1997; 217-2443.

43. Gibson $\mathrm{AH}$. Host determinants in nodulation and nitrogen fixation. In: Summerfield RJ, Bunting AH, (eds.). Advances in legume science. Royal Botanic Garden, Kew, UK. 1980;69-75.

(C) 2017 Agele et al.; This is an Open Access article distributed under the terms of the Creative Commons Attribution License (http://creativecommons.org/licenses/by/4.0), which permits unrestricted use, distribution, and reproduction in any medium, provided the original work is properly cited.

Peer-review history:

The peer review history for this paper can be accessed here: http://sciencedomain.org/review-history/20078 